\title{
STATUS LEUKOSIT DAN DIFFERENTIAL LEUKOSIT TIKUS PUTIH (Rattus norvegicus L.) PERIODE LAKTASI SETELAH DIBERI SUPLEMEN TELUR PUYUH ORGANIK
}

\section{Leukocyte Status and Differential Leukocytes of Rats (Rattus norvegicus L.) Lactation Period After Giving Supplements Organic Quail Eggs}

\author{
Hasan Basri \\ Program Studi Biologi, Fakultas Matematika dan Ilmu Pengetahuan Alam, \\ Universitas Islam Al azhar, Mataram, Indonesia \\ E-mail: hasanbasri7491@gmail.com
}

\begin{abstract}
The purpose of this research is to know the status of the Leukocyte differential leukocyte and rats (Rattus norvegicus L.) lactation period after the grant of a supplement to the quail eggs are organic. This research is a type of experimental research with Random Design complete using 4 treatments and 5 replicates. The data obtained were analyzed with Anova, if there is a real difference continued test Duncan at $95 \%$ confidence level $(\alpha=0.05)$. Analysis with the software SPSS 16.0 for windows. T0: Control Treatment; T1: (Rattus norvegicus L.) lactation period were given supplements of the eggs produced by quail fed commercial feed; T2: (Rattus norvegicus L.) lactation period were given supplements of the eggs produced by a given organic feed quail standard; T3: (Rattus norvegicus L.) lactation period were given supplements of the eggs produced by quail fed organic feed. Based on the number of leukocytes results showed different results real $(\mathrm{P}<$ 0.05), the number of neutrophils, basophils, esonofil shows a different result is not real $(\mathrm{P}>0.05)$, whereas the number of lymphocytes showed different results real $(\mathrm{P}<0.05)$. Supplementation of organic quail eggs could be maintaining the condition Leukocyte status in the lactation period of (Rattus norvegicus L.).
\end{abstract}

Keywords: Leukocyte Status, and Differential Leukocytes., Rattus norvegicus L., Organic Quail Eggs. 


\section{PENDAHULUAN}

Perubahan status hematologis dapat digunakan untuk mendeteksi adanya gangguan metabolisme, penyakit, kerusakan struktur pada fungsi organ, pengaruh agen atau obat, dan stres (Aderemi, 2004; Iheidioha et al., 2012). Pemeriksaan hematologis mempunyai nilai lebih dalam proses membantu menegakkan diagnosa atau menjadi bagian dalam program monitoring penyakit metabolik (Lager \& Jordan, 2012). Status hematologis berguna untuk menilai kondisi kesehatan (Togun et al., 2007) pada saat bunting dan laktasi.

Periode bunting dan laktasi paling rentan terjadi anemia dan imunitasnya menurun. Faktor yang mempengaruhi anemia dan imun menurun di antaranya: nutrisi, lingkungan, usia, jenis kelamin dan genetik (Tras et al., 2000; Addass et al., 2012). Kekurangan nutrisi Fe pada kehamilan dan laktasi juga menyebabkan menurunnya produksi air susu, terjadi gangguan dalam kehamilan baik pada induk dan janin yang dikandungnya (Xiong et al., 2003; Arisman, 2010). Di samping itu, pada saat proses kelahiran, induk kehilangan banyak darah, pada tubuh yang sehat kehilangan darah ini akan dipulihkan kembali melalui proses hematopoiesis dengan cara pembentukan sel darah baru. Sel-sel darah baru ini digunakan untuk mengganti darah yang hilang atau rusak hal ini penting dalam menopang berlangsungnya produksi air susu pada periode laktasi (Xiong et al., 2003).

Dalam pembentukan sel-sel darah baru dibutuhkan pakan dengan nilai nutrisi yang tinggi. Salah satu alternatif untuk mensuplai kebutuhan nutrisi yaitu dengan mengkonsumsi telur puyuh organik. Telur puyuh organik merupakan telur yang dihasilkan oleh puyuh yang diberi pakan organik, yang bersumber dari organisme hidup (hewan atau tumbuhan) (Basri et al., 2018). Kadar kolestrol kuning telur puyuh yang diberi serbuk kunyit 108 mg/ekor/hari sebesar 653.20 \pm 12.67 mg/dl (Putra et al., 2016).

Telur puyuh organik mengandung vitamin A, protein, karbohidrat, mineral dan asam lemak esensial yang baik untuk kesehatan. Telur puyuh organik juga mengandung kadar kolesterol yang rendah dan kandungan nutrisi yang tinggi. 
Kelengkapan zat nutrisi dalam makanan ternak akan dapat mempercepat pubertas, estrus pertama setelah melahirkan, menjaga kebuntingan, berat anak lahir, berat anak setelah sapih serta menjaga kondisi induk saat laktasi (Yendraliza, 2013).

Pemeriksaan leukosit bisa menggambarkan kondisi fisiologis tubuh yang terjadi pada periode laktasi, di mana leukosit berperan sebagai imunitas tubuh terhadap infeksi dan peradangan akut yang ringan (Sadikin, 2002; Stephen \& William, 2010). Makrofag berperan dalam inflamasi kronik. Makrofag berasal dari sel induk monosit dalam sumsum tulang belakang, yang mempunyai masa hidup yang lebih lama dari fagosit granulosit yang bersirkulasi dan tetap bekerja pada tingkat keasaman yang lebih rendah (Kumar et al., 2005).

Hasil penelitian Ewuola et al., (2015) menyatakan bahwa pemberian Moringa oleifera dengan dosis T2 $100 \mathrm{~mL} \mathrm{CMOLE/L,}$ T3 $200 \mathrm{~mL}$ CMOLE/L, T4 $300 \mathrm{~mL}$ CMOLE/L menunjukkan hematologis (nilai eritrosit, hematokrit, hemoglobin, leukosit, diferensial leukosit) kelinci selama kehamilan dan laktasi berada dalam kisaran normal. Pemberian Moringa oleifera pada kelinci selama kehamilan dan laktasi memiliki status hematologis dan imunitas yang baik. Berdasarkan latar belakang tersebut, maka peneliti menguji efek pemberian suplemen telur puyuh organik terhadap status leukosit dan differential leukosit tikus putih (Rattus norvegicus) selama periode laktasi.

\section{METODE PENELITIAN}

\section{a. Waktu dan Tempat Penelitian}

Penelitian dilakukan di Laboratorium Struktur dan Fungsi Hewan Jurusan Biologi Fakultas Sains dan Matematika (FSM) Universitas Diponegoro Semarang (tempat penelitian pemberian perlakuan) dan Laboratorium Wahana (AnalysisChemical Distributor-Consultant) Semarang (menganalisis leukosit dan differensial leukosit tikus putih).

\section{b. Rancangan Penelitian}

Penelitian ini merupakan jenis penelitian eksperimental dengan Rancangan Acak Lengkap (RAL). Penempatan hewan uji 
pada setiap perlakuan dilakukan secara random. Hewan uji yang digunakan pada penelitian ini adalah tikus putih (R. norvegicus L.) bunting 20 ekor yang diambil secara acak dari 30 ekor tikus putih (R. norvegicus L.) dengan umur 2 bulan dan berat badan rerata \pm 200 g. Tikus putih (R. norvegicus L.) bunting yang sudah diambil tersebut dibagi dalam 4 kelompok perlakuan. Masing-masing kelompok perlakuan terdiri dari 5 ulangan. Setiap ulangan terdiri dari 5 ekor tikus putih (R. norvegicus L.) bunting yang ditempatkan 1 kandang 1 ekor tikus putih. T0: sebagai kelompok perlakuan kontrol yang diberi pakan komersial; T1: kelompok perlakuan yang diberi telur yang diproduksi oleh puyuh (P0); T2: kelompok perlakuan yang diberi telur yang diproduksi oleh puyuh (P1); T3: kelompok perlakuan yang diberi telur yang diproduksi oleh puyuh (P2) (Tabel 1). Variabel yang dianalisis adalah jumlah leukosit, jumlah neutrofil, jumlah eosinofil, jumlah basofil, jumlah limfosit dan jumlah monosit.

\section{HASIL DAN PEMBAHASAN}

Telur puyuh organik merupakan telur yang dihasilkan oleh burung puyuh yang diberi pakan organik, yang bersumber dari organisme hidup (hewan atau tumbuhan). Kandungan kimiawi telur puyuh non-organik dan organik yang diproduksi dari puyuh (P0), (P1) dan (P2) disajikan pada Tabel 1.

Tabel 1.

Kandungan kimiawi telur puyuh P0, P1 dan P2

\begin{tabular}{llll}
\hline Kandungan Nutrisi & P0 & P1 & P2 \\
\hline Protein (\%) & 12.63 & 12.67 & 13.02 \\
Lemak (\%) & 11.12 & 11.26 & 11.31 \\
Karbohidrat (\%) & 0.87 & 0.91 & 0.88 \\
Air (\%) & 74.33 & 74.29 & 74.77 \\
Abu (\%) & 0.75 & 0.69 & 0.73 \\
Ca (mg/100gr) & 51.89 & 52.12 & 54.03
\end{tabular}


Basri, $\mathrm{H}$

\begin{tabular}{llll} 
Fe (mg/100gr & 2.65 & 2.73 & 2.70 \\
Cu (mg/kg) & 0.104 & 0.109 & 0.103 \\
Zn (mg/kg & 1.04 & 1.08 & 1.08 \\
\hline
\end{tabular}

Keterangan: P0: telur puyuh biasa yang diproduksi dari puyuh yang diberi pakan komersial, P1: telur puyuh organik yang diproduksi dari puyuh yang diberi pakan organik standar, P2: telur puyuh organik yang diproduksi dari puyuh yang diberi pakan organik standar yang ditambah suplemen.

Hasil perhitungan status hematologis yang meliputi jumlah leukosit total dan diferensial leukosit (neutrofil, eosinofil, basofil, limfosit dan monosit) tikus putih (R. norvegicus L.) yang diberi suplemen telur puyuh organik sampai periode laktasi tersaji pada Tabel 2.

Tabel 2.

Hasil analisis jumlah leukosit total dan diferensial leukosit tikus putih $(R$. norvegicus L.) periode laktasi.

\begin{tabular}{|c|c|c|c|c|}
\hline \multirow[b]{2}{*}{ Status Hematologis } & \multicolumn{4}{|c|}{ Perlakuan } \\
\hline & T0 & T1 & $\mathrm{T} 2$ & T3 \\
\hline $\begin{array}{l}\text { Leukosit } \\
\left(\times 10^{3} / \mathrm{mm}^{3}\right)\end{array}$ & $16,24^{b} \pm 2.03$ & $19,48^{\mathrm{a}} \pm 1.42$ & $14,52^{\mathrm{b}} \pm 0.56$ & $17,34^{\mathrm{ab}} \pm 1.68$ \\
\hline $\begin{array}{l}\text { Neutrofil } \\
\left(\times 10^{3} / \mathrm{mm}^{3}\right)\end{array}$ & $1.43^{\mathrm{a}} \pm 0.71$ & $1.40^{\mathrm{a}} \pm 0.37$ & $1.48^{a} \pm 0.65$ & $1.63^{a} \pm 0.69$ \\
\hline $\begin{array}{l}\text { Eosinofil } \\
\left(\times 10^{3} / \mathrm{mm}^{3}\right)\end{array}$ & $0.81^{\mathrm{a}} \pm 0.20$ & $0.70^{\mathrm{a}} \pm 0.35$ & $0.61^{\mathrm{a}} \pm 0.18$ & $0.66^{\mathrm{a}} \pm 0.33$ \\
\hline Basofil $\left(\times 10^{3} / \mathrm{mm}^{3}\right)$ & $0.22^{\mathrm{a} \pm 0.08}$ & $0.31^{\mathrm{a} \pm 0.11}$ & $0.21 \mathrm{a} \pm 0.07$ & $0.21^{\mathrm{a} \pm 0.08}$ \\
\hline Limfosit $\left(\mathrm{x}^{3} \mathrm{10}^{3} / \mathrm{mm}^{3}\right)$ & $12.50^{\mathrm{bc}} \pm 0.89$ & $17.03^{\mathrm{a}} \pm 2.66$ & $10.66^{\mathrm{c}} \pm 1.05$ & $13.14^{b} \pm 0.95$ \\
\hline Monosit $\left(\mathrm{x}^{10^{3}} / \mathrm{mm}^{3}\right)$ & $0.75^{\mathrm{a}} \pm 0.08$ & $0.86^{\mathrm{a}} \pm 0.35$ & $0.87 a \pm 0.10$ & $1.04^{\mathrm{a}} \pm 0.21$ \\
\hline
\end{tabular}

Keterangan: Angka yang diikuti dengan superscript yang sama dalam baris yang sama menunjukkan tidak berbeda nyata $(\mathrm{P}>0,05)$. T0: Perlakuan (kontrol), T1: perlakuan yang diberi telur puyuh biasa dengan 1 butir telur /ekor/hari, T2: perlakuan yang diberi telur puyuh organik standar dengan 1 butir telur /ekor/hari, T3: perlakuan yang diberi telur puyuh organik dengan 1 butir telur /ekor/hari.

Hasil analisis pemberian suplemen telur puyuh organik pada tikus putih (R. norvegicus L.) laktasi terhadap jumlah leukosit menunjukkan hasil yang berbeda nyata $(\mathrm{P}<0,05)$, jumlah 
neutrofil, esonofil, basofil menunjukkan hasil yang berbeda tidak nyata $(\mathrm{P}>0,05)$, sedangkan jumlah limfosit menunjukkan hasil yang berbeda nyata $(\mathrm{P}<0,05)$. Menurut Lindstrom et al., (2015), jumlah leukosit total pada tikus putih (R. norvegicus L.) tidak laktasi sebesar 6.6-12.6 x103/mm3. Hasil perhitungan jumlah leukosit total tikus putih (R. norvegicus L.) pada keadaan laktasi sebesar 14.52-19.48 x103/mm3. Hasil perhitungan jumlah leukosit total pada tikus putih (R. norvegicus L.) laktasi pada semua perlakuan berada di atas jumlah leukosit total pada tikus putih (R. norvegicus L.) yang tidak sedang laktasi. Peningkatan jumlah leukosit total pada tikus putih (R. norvegicus L.) laktasi merupakan respon fisiologis yang disebabkan oleh inflamasi. Menurut Anderson \& Lorraine (2006) peningkatan jumlah sel leukosit merupakan terjadinya inflamasi akut. Hal ini disebabkan oleh makromolekul protein pada pakan dan stres. Kresno (2007) menyatakan imunogen yang paling poten adalah makromolekul protein dengan berat molekul $>100.000$. Bayyinatul et al (2012) menambahkan protein dengan berat molekul lebih dari $100 \mathrm{kDa}$ merupakan imunogen kuat.

Kisaran normal jumlah neutrofil pada tikus putih (R. norvegicus L.) tidak sedang laktasi sebesar 0.01-1.19 (x103/mm3) (Mathers et al., 2007), sedangkan pada hasil perhitungan jumlah neutrofil pada tikus putih (R. norvegicus L.) dalam keadaan laktasi sebesar 1.40-1.63 (x103/mm3), hal ini disebabkan sel neutrofil merupakan garis pertahanan seluler pertama dalam proses peradangan, serta berperan penting dalam proses fagositosis dan membunuh mikroorganisme.

Kisaran normal eosinofil pada tikus putih (R. norvegicus L.) tidak laktasi sebesar (0-1.96) (x103/mm3) (Lindstrom et al., 2015), sedangkan hasil perhitungan jumlah eosinofil pada tikus putih (R. norvegicus L.) laktasi sebesar (0.61-0.81) x103/mm3. Hal ini menunjukkan bahwa pemberian suplemen telur puyuh organik pada tikus putih (R. norvegicus L.) periode laktasi tidak menimbulkan pengaruh yang signifikan terhadap jumlah eosinofil.

Hasil perhitungan jumlah basofil di atas dari nilai normal pada tikus putih (R. norvegicus L.) tidak sedang laktasi (0-0.4) (x103/mm3) (Lindstrom et al., 2015), sedangkan hasil perhitungan jumlah basofil pada tikus putih laktasi sebesar 0.21- 
$0.31 \times 103 / \mathrm{mm} 3$. Peningkatan jumlah basofil pada tikus putih (R. norvegicus L.) laktasi menunjukkan terjadinya inflamasi. Menurut Pagana \& Emeritus, (2007) menyatakan peningkatan jumlah basofil menunjukkan terjadinya gangguan berupa inflamasi. Terjadinya proses inflamasi diinisiasi oleh perubahan di dalam pembuluh darah yang meningkatkan aktivitas leukosit dan perpindahan cairan serta protein plasma di dalam jaringan. Proses tersebut merupakan langkah pertama untuk memulihkan jaringan yang rusak (Abbas et al., 2012).

Jumlah limfosit dalam uji lanjut dengan uji Duncan terdapat perbedaan nyata pada T1 dengan T0; T1 dengan T3; T1 dengan T2. Rata-rata semua perlakuan jumlah limfosit berada di atas nilai normal pada tikus putih (R. norvegicus L.) tidak sedang laktasi. Kisaran normal jumlah limfosit pada tikus putih (R. norvegicus L.) tidak sedang laktasi sebesar 4.81-6.94 (x103/mm3) (McDonogh at al., 2015), sedangkan hasil penelitian jumlah limfosit pada tikus putih (R. norvegicus L.) dalam keadaan laktasi sebesar 10.6617.03 (x103/mm3) Tabel 2. Price dan Wilson (2005) menyatakan bahwa jumlah limfosit akan meningkat sebagai respon terhadap imunitas tubuh dan gangguan fisiologis.

Pemberian suplemen telur puyuh organik tidak mempengaruhi jumlah monosit baik pada tikus putih (R. norvegicus L.) yang tidak diberi suplemen telur puyuh organik pada perlakuan T0, pada perlakuan T1 yang diberi telur puyuh biasa (P0), pada perlakuan T2 yang diberi telur puyuh organik standar (P1) dan pada perlakuan T3 yang diberi telur puyuh organik (P2). Rata-rata jumlah monosit semua perlakuan berada di atas nilai normal pada tikus putih (R. norvegicus L.) tidak sedang laktasi. Kisaran normal jumlah monosit pada tikus putih (R. norvegicus L.) tidak sedang laktasi sebesar 0.41-0.65 (x103/mm3) (McDonogh et al., 2015), sedangkan pada hasil perhitungan dalam keadaan laktasi sebesar 0.75-1.04 (x103/mm3). Menurut Abbas et al., (2012), stimulus dapat menyebabkan monosit dalam sirkulasi darah bergerak dalam jumlah besar ke jaringan, kejadian ini dapat memicu jumlah monosit dalam sirkulasi menjadi berkurang.

\section{KESIMPULAN}


Jumlah granulosit neutrofil, eosinofil dan basofil masih dalam kisaran fisiologis normal. Sel leukosit agranulosit limfosit dan monosit berada di atas dari nilai normal namun tidak mempengaruhi kondisi fisiologis induk tikus putih (R. norvegicus L.) periode laktasi. Dengan demikian, dapat disimpulkan bahwa pemberian suplemen telur puyuh organik mampu menjaga status leukosit pada tikus putih periode laktasi.

\section{DAFTAR PUSTAKA}

Abbas, K.A., Lichtman. A.H \& Pober, J.S. (2012). Cells and Tisue of the Immune System. Dalam: Cellular and Molecular Immunology, $4^{\text {th }}$ ed. Philadelphia, WB Saunders Co. pp 1740.

Addass, P.A., David, D.L., Edward, A., Zira, K.E., \& Midau. A. (2012). Effect of Age, Sex and Management System on Some Haematological Parameters of Intensively and SemiIntensively Kept Chicken in Mubi, Adamawa State, Nigeria. Iranian Journal of Applied Animal Science. 2(3),277-282.

Aderemi, F.A. (2004). Effects of Replacement of Wheat Bran with Cassava Root Sieviate Supplemented or Unsupplemented with Enzyme on the Haematology and Serum Biochemistry of Pullet Chicks. Tropical Journal Animal Science. 7:147-153.

Anderson, S.P., \& Lorraine, M.W. (2006). Patofisiologi Konsep Klinis Proses-Proses Penyakit. Edisi 6. Jakarta. EGC.

Arisman, (2010). Gizi Dalam Kehidupan. Buku Ajar Ilmu Gizi. EGC.

Basri, H., Saraswati, T.R., \& Isdadiyanto, S. (2018). Hematological status of rats (Rattus norvegicus L.) in the lactation period after giving supplements organic quail eggs. International Journal of Biological Research, 6 (1), 1-4. 
Bayyinatul, M., Sutiman, B.S., Soemarno., \& Trini, S. (2012). Isolasi dan Karakterisasi Protein 100 kDa dari Membran Kepala Spermatozoa Kambing. J. Exp. Life Sci. 2(1),13-19.

Gandasoebrata, R. (2013). Penuntun Laboratorium Klinik. cet.15. Jakarta: Dian Rakyat. hal 11-34.

Ihedioha, J.I., Ugwuja, J.I., Noel-Uneke, O.A., Udeani, I.J., \& DanielIgwe, G. (2012). Reference Values for the Haematology Profile of Conventional Grade Outbred Albino Mice (Mus musculus) in Nsukka, Eastern Nigeria. ARI. Vol 9(2),16011612.

Kresno, S.B. (2007). Imunologi: Diagnosis dan Prosedur Laboratorium. Edisi IV. Cetakan ke3. Balai Penerbit FKUI, Jakarta. Hal 1498.

Lager, K., \& Jordan, E. (2012). The Metabolic Profile for the Modern Transition Dairy Cow. The Mid-South Ruminant Nutrition Conference. Texas Agrilife Extension Service, Texas.

Lindstrom, N.M., Zimmerman, K., Moore, D.M., \& Smith, S.A. (2015). Hematologic Assessment in Pet Rats, Mice, Hamsters, and Gerbils Blood Sample Collection and Blood Cell Identification. Clin Lab Med (35) 629-640. http://dx.doi.org/10.1016/j.cll.2015.05.011.

Mathers, R.A., Evans, G.0., Bleby, J., \& Tornow, T. (2007). Total and Differential Leucocyte Counts in Ratand Mouse Bronchoalveolar Lavage Fluidsusing the Sysmex XT2000iV. Comp Clin Pathol, 16:29-39. DOI 10.1007/s00580-006-0655-x.

McDonogh, T.L., Thompson, P.P., Sangster, C.R., Meagher, P.J.B., \& Vogelnest, L. (2015). Hematologic and Biochemical Reference Values of the Australian Bush Rat (Rattus fuscipes). Journal of Wildlife Diseases, 51(3), 795-799. 
Sadikin, M., \& Haji, D. (2002). Biokimia Darah Cetakan I. Jakarta: Widya Medika.

Stephen, J.M., \& William, F.G. (2010). Patofisiologi Penyakit Pengantar Menuju Kedokteran Klinik Edisi V. EGC. Jakarta.

Pagana. J., \& Emeritus. (2007). Mosby's Manual of Diagnostic and Laboratory Tests. White Blood Cell Count and Differential Count (WBC and Differential, Leukocyte Count, Neutrophil Count, Lymphocyte Count, Monocyte Count, Eosinophil Count, Basophil Count). $5^{\text {th }}$ Ed. Pennsylvania: Elsevier. pp 880-6.

Parasuraman, S. Raveendran, R. Kesavan, R. (2010). Blood sample collection in small laboratory animals. Journal Pharmacol Pharmacother, 1: 87-93.

Price \& Wilson. (2005). Konsep Klinis Proses-Proses Penyakit. Edisi 6. EGC. Jakarta. Vol.2.

Tambur, Z. (2006). White Blood Cell Differential Count in Rabbits Artificially Infected with Intestinal Coccidia. J. Protozool. Res, 16, 42-50.

Togun, V.A., Oseni, B.S.A., Ogundipe, J.A., Arewa, T.R., Hammed, A.A., Ajonijebu, D.C \& Mustapha, F. (2007). Effects of Chronic Lead Administration on the Haematological Parameters of Rabbits - a Preliminary Study (p. 341). Proceedings of the 41st Conferences of the Agricultural Society of Nigeria.

Tras, B., Inal, F., Bas, A.L., Altunok, V., Elmas, M., \& Yazar, E. (2000). Effects of Continuous Supplementations of Ascorbic Acid, Aspirin, Vitamin E and Selenium on some Haematological Parameters and Serum Superoxide Dismutase Level in Broiler Chickens. British Poultry Science, 41(5),664-666. 
Basri, $\mathrm{H}$

Xiong, X., Buekens, P., Fraser, W.D., \& Guo, Z. (2003). Anemia During Pregnancy in a Chinese Population. Int. J. Gynaecol. Obstet, 83,159-64. 